\title{
Influence of biomass aerosol on precipitation over the Central Amazon: an observational study
}

\author{
W. A. Gonçalves ${ }^{1}$, L. A. T. Machado ${ }^{1}$, and P.-E. Kirstetter ${ }^{2}$ \\ ${ }^{1}$ National Institute for Space Research-INPE/Center for Weather Forecasting and Climate Studies-CPTEC, \\ Cachoeira Paulista, São Paulo, Brazil \\ ${ }^{2}$ Advanced Radar Research Center/University of Oklahoma and NOAA National Severe Storm Laboratory, Oklahoma, USA \\ Correspondence to: W. A. Gonçalves (goncalves.weber@gmail.com)
}

Received: 06 June 2014 - Published in Atmos. Chem. Phys. Discuss.: 18 July 2014

Revised: 21 April 2015 - Accepted: 13 May 2015 - Published: 18 June 2015

\begin{abstract}
Understanding the influence of biomass burning aerosol on clouds and precipitation in the Amazon is key to reducing uncertainties in simulations of climate change scenarios with regard to deforestation fires. Here, we associate rainfall characteristics obtained from an S-band radar in the Amazon with in situ measurements of biomass burning aerosol for the entire year of 2009. The most important results were obtained during the dry season (July-December). The results indicate that the influence of aerosol on precipitating systems is modulated by the atmospheric degree of instability. For less unstable atmospheres, the higher the aerosol concentration is, the lower the precipitation is over the region. In contrast, for more unstable cases, higher concentrations of black carbon are associated with greater precipitation, increased ice content, and larger rain cells; this finding suggests an association with long-lived systems. The results presented are statistically significant. However, due to limitations imposed by the available data set, important features, such as the contribution of each mechanism to the rainfall suppression, need further investigation. Regional climate model simulations with aircraft and radar measurements would help clarify these questions.
\end{abstract}

\section{Introduction}

Every year, the Amazon forest faces a large amount of aerosol pollution from pasture and forest fires, and the generated pollution plumes can spread over large areas (Martin et al., 2010). The biomass burning aerosol (BBA) in the Amazon can alter atmospheric particulate material composition
(Ryu et al., 2007) and influence cloud formation, precipitation, and the radiation budget (Artaxo et al., 2002; Lin et al., 2006; Tao et al., 2012; Camponogara et al., 2014). According to Tegen et al. (1997), BBA predominates in the mean annual aerosol optical thickness in the Amazon. The dry season, which occurs between July and December, is the period that faces greater biomass burning emissions (Artaxo et al., 2002; Altaratz et al., 2010; Martin et al., 2010; Camponogara et al., 2014). However, from January to June (the wet period), BBA is also observed in the Amazon basin (Martin et al., 2010).

In recent years, the scientific community has made great efforts to understand the effect of aerosols on clouds and precipitation to reduce uncertainties in climate prediction (Tao et al., 2012). Two main effects are well documented: radiative or semi-direct, and microphysical or indirect effects. The first effect is related to BBA's high capacity for absorption in the visible portion of the electromagnetic spectrum (Hansen et al., 1997; Ramanathan et al., 2001; Wake, 2012). This absorption could warm the atmosphere (Koren et al., 2004; Randles and Ramaswamy, 2010; Koch and Del Genio, 2010; Jacobson, 2014) and produce atmospheric stabilization (Johnson et al., 2004; Koren et al., 2008). The semi-direct effect alters the atmospheric temperature in the boundary layer, depending on the level at which the aerosol is presented (Randles and Ramaswamy, 2010). Johnson et al. (2004) commented that in cases of absorbing aerosol located above the boundary layer, the effect is the opposite, i.e., that the boundary layer suffers a radiative cooling. Boundary layer warming only occurs when the absorbing aerosols are constrained in the low atmosphere. The indirect or micro- 
physical effect is linked to the possibility of BBA particles becoming cloud condensation nuclei (Roberts et al., 2001). As a result, it is expected that the quantity of cloud droplets would increase with the particle concentration (Rosenfeld, 1999; Ramanathan et al., 2001; Andreae et al., 2004; Qian et al., 2009).

One of the most important issues regarding the analysis of aerosol-cloud interactions is the determination of the predominant effect: radiative or microphysical. In warm rain suppression conditions, both effects seem to act together. However, the quantification of their respective contributions remains an important issue. Warm rain suppression evidence was firstly documented by Rosenfeld (1999), and similar results have subsequently been presented in literature, e.g., Koren et al. (2004) and Qian et al. (2009). The physical mechanism suggested for warm rain suppression is related to the fact that BBA has the potential to act as cloud condensation nuclei. Thus, in polluted environments, a large number of small cloud droplets could form (Rosenfeld, 1999; Ramanathan et al., 2001; Andreae et al., 2004; Qian et al., 2009), which compromises the coalescence process (Borys at al., 2000; Hudson and Yum, 2001; McFarquhar and Heymsfield, 2001; Yum and Hudson, 2002; Borys et al., 2003; Hudson and Myshra, 2007; Kaufman et al., 2005). These droplets do not reach the required size to precipitate and can rapidly evaporate due to the semi-direct effect (Artaxo et al., 2006). However, as previously mentioned, the atmospheric level at which the BBA is located could lead to different results. Even boundary layer cooling is likely to be observed. This could explain some of the controversy observed in literature. Kaufman et al. (2005) and Brioude et al. (2009), for example, obtained results that differed from those demonstrated in other warm rain suppression publications. In these studies, the authors observed an increase in stratiform cloud formation in cases with an elevated presence of aerosols.

In addition to the influence of BBA on warm rain, icephase cloud development is affected in polluted environments. In fact, laboratory measurements indicate a high capacity for ice nucleation by BBA (Petters et al., 2009). In recent years, some studies have suggested that ice-phase clouds are invigorated by the presence of aerosols from vegetation fires (Andreae et al., 2004; Lin et al., 2006; Rosenfeld et al., 2008; Altaratz et al., 2010; Koren et al., 2012; Storer and Heever, 2013). Rosenfeld et al. (2008) have proposed a conceptual model based on the effect of aerosols on deep convective cells, one that is mainly associated to the microphysical effect. According to the authors, due to the high concentration of aerosols in polluted environments, raindrop nucleation will be slower than in unpolluted areas. This process delays the initiation of precipitation, leading the droplets and aerosols to ascend into the atmosphere and reach the frozen layer. In addition, these droplets and aerosols could act as ice nuclei and release latent heat, which could increase updrafts and invigorate cloud dynamics (Lin et al., 2006; Rosenfeld et al., 2008). However, even with this evidence, the cloud invig- oration process by aerosols still needs to be better understood (Altaratz et al., 2014).

Although well documented, particularly in recent studies, the BBA effect on clouds and precipitation is still a source of debate in the scientific community. One of the most important outstanding issues is related to filtering the aerosolprecipitation relationship from other dominant atmospheric processes. To reach this goal, this study presents a new methodology based on the atmospheric degree of instability. The use of ground-based measurements has the potential to contribute to present scientific knowledge on the influence of BBA on precipitating cells in the Amazon region. Parameters of rain, ice content, size, and duration of precipitating systems retrieved from an S-band radar were evaluated as functions of black carbon (BC) concentration over the largest Amazon city (Manaus, Amazonas state, Brazil).

\section{Data analysis}

All analyses performed in this study were performed using a combination of four data sets:

1. Terrain elevation data at a $90 \times 90 \mathrm{~m}^{2}$ resolution from the Shuttle Radar Topography Mission (SRTM) were employed.

2. Weather radar data from the Manaus S-band Doppler radar $\left(1 \times 1 \mathrm{~km}^{2}\right.$ horizontal resolution in a range of $100 \mathrm{~km}$, updated every $11 \mathrm{~min}$ ) were utilized.

3. BC concentration data were taken from the European Integrated project on Aerosol Cloud Climate and Air Quality Interactions (EUCAARI) experiment, with a sampling time of $1 \mathrm{~min}$ and averaging every $30 \mathrm{~min}$. The EUCAARI experiment used a multi-angle absorption photometer (MAAP) instrument (Slowik et al., 2007) and collected data $50 \mathrm{~km}$ away from Manaus city. The $\mathrm{BC}$ concentrations were used in the study as aerosol tracer data.

4. Atmospheric soundings from the Manaus station were used to calculate the convective available potential energy (CAPE), an important atmospheric index used as an intense convective activity predictor (Wallace and Hobbs, 2006). As Manaus radiosondes were released by an operational station, only soundings at 00:00 and 12:00 UTC, 08:00 and 20:00 local time, were available. The most appropriate time for a sounding in this study was approximately noon; this is when convection starts to develop in the area. However, the CAPE data set was evaluated and shown to have substantially useful information and the ability to capture daily instability features, even though the recordings were not made at the most appropriate times. The 08:00 local time soundings also presented a considerable population of high CAPE values (greater than $2600 \mathrm{~J} \mathrm{~kg}^{-1}$ ). In addition, more than 
$70 \%$ of the days that had CAPE values higher than $2600 \mathrm{~J} \mathrm{~kg}^{-1}$ at 00:00 UTC presented high CAPE values the next morning (as measured at 12:00 UTC).

Notably, BC is a byproduct of the partial combustion of fossil fuels or a remnant of wildfires (Ahmed et al., 2014), and it represents only approximately $5 \%$ of the total carbon concentration resulting from biomass burning (Formenti et al., 2001; Graham et al., 2003; Cozic et al., 2008). However, BBA dominates the aerosol concentration in the Amazon basin, allowing for the use of $\mathrm{BC}$ as an aerosol tracer. $\mathrm{BC}$ concentration is well correlated with aerosol concentration in the Amazon. Several studies in Amazonia have demonstrated this relationship. Bevan et al. (2009) used a 13-year time series of Along Track Scanning Radiometer (ATSR)-derived aerosol optical depth (AOD) measurements to examine the role of aerosol in the interaction with biomass burning over the Amazon. AOD has a significant positive correlation with the total number of satellite-observed fires. Additionally, numerous studies have used aerosol particles greater than $80 \mathrm{~nm}$ as a proxy for cloud condensation nuclei (CCN). D' Andrea et al. (2013) and Liu and Li (2014) commented on the positive relationship between aerosol concentrations and $\mathrm{CCN}$.

$\mathrm{BC}$ has received attention by the scientific community due to its potential for ice nucleation, which can affect the microphysical properties of clouds (Cattani et al., 2006; Cozic et al., 2008). The supersaturation required for ice formation decreases with the presence of BC (DeMott et al., 1999). Cozic et al. (2008) found that a portion of the cloud droplet nuclei present in mixed-phase clouds comprises BC. Therefore, due to its potential for ice nucleation, the presence of $\mathrm{BC}$ would favor the invigoration of pre-existing ice-phase clouds, including deep convection. As previously discussed, $\mathrm{BC}$ also has the capacity to absorb radiation in the visible portion of the electromagnetic spectrum (Ramanathan et al., 2001; Storelvmo, 2012; Tiwari et al., 2013; Ahmed et al., 2014). This characteristic could warm the layer where $B C$ is present (Myhre, 2009; Mahowald, 2011; Jones et al., 2011; Wake, 2012; Wang, 2013), which could stabilize the atmosphere and reduce the formation of cumulus clouds. In turn, this characteristic of $\mathrm{BC}$ could also affect cloud properties and precipitation indirectly, as discussed above.

The S-band radar data were processed following the TRADHy (Traitements Régionalisés et Adaptatifs de Données Radar pour l'Hydrologie - Regionalized and Adaptive Radar Data Processing for Hydrological Applications) strategy (Delrieu et al., 2009), briefly described hereafter. A preliminary quality control of the radar data was performed, and the radar calibration was checked throughout the year 2009. The area actually sampled by the radar was determined for each elevation angle along with a characterization of partial or complete beam blockage and ground clutter. Rain types and the corresponding vertical profiles of reflectivity (VPRs) were dynamically identified. Regarding VPR identification, the initial method used in TRADHy performs a numerical identification of VPRs from the comparison of the radar data at different distances and altitudes to account for sampling effects (Kirstetter et al., 2010). In the present study, the physical approach described by Kirstetter et al. (2013) was used to identify, with enhanced robustness, a representative VPR over the radar domain for a given precipitation type. Corrections for both clutter and beam blockage were performed along with a projection of measured reflectivities onto the ground level using rain-typed VPRs. At a given pixel, reflectivities from all available elevation angles were used for the projection. The projected radar reflectivity of a constant altitude plan at the same elevation as the radar was called the Constant Altitude Plan Position Indicator-Ground (CAPPIGround). The vertical ice content (VIC) for each pixel of the radar images was also calculated. The method described in Kirstetter et al. (2013) is based on a modeling of the physical properties of the hydrometeors (size distribution, shape, phase, electromagnetic properties, etc.) contributing to the VPR features. In particular, the model for the ice phase above the freezing level allows for the computation of the VIC. The identified VPR is then associated to a model for the ice phase, which is used to compute the VIC at each pixel alongside the projection of reflectivity at the surface.

To determine the general behavior of precipitation in the study area, as well as its relationship with particulate material, three indices were used as follows:

$$
\begin{aligned}
& \mathrm{RF}=N_{20 \mathrm{dBZ}} / N_{\text {TOTAL }} \times 100 \\
& \mathrm{IRF}=N_{45 \mathrm{dBZ}} / N_{\text {TOTAL }} \times 100 \\
& \mathrm{IF}=N_{1 \mathrm{~mm}} / N_{\text {TOTAL }} \times 100,
\end{aligned}
$$

where RF is the rain fraction, IRF is the intense rain fraction, and IF is the ice fraction. $N_{20 \mathrm{dBZ}}$ is the number of CAPPIGround pixels with a reflectivity equal or higher than $20 \mathrm{dBZ}$, $N_{45 \mathrm{dBZ}}$ is the number of CAPPI-Ground pixels with a reflectivity equal or higher than $45 \mathrm{dBZ}, N_{1 \mathrm{~mm}}$ is the number of VIC pixels equal or higher than $1 \mathrm{~mm}$, and $N_{\text {TOTAL }}$ is the sum of pixels in the area.

The three indices described above indicate the spatial distribution of the rain properties in the study domain. The higher their value, the greater the part of the study area covered by the physical property analyzed. The RF and IRF indices express how the rain and the intense rain are distributed in the domain according to the respective thresholds of 20 and $45 \mathrm{dBZ}$, which approximately correspond to rain rates of 1 and $30 \mathrm{~mm} \mathrm{~h}^{-1}$, respectively, according to Marshall and Palmer (1948). IF indicates the percentage of the area covered by ice clouds. As previously described, the value of $1 \mathrm{~mm}$ was chosen from the VPR method to determine IF. Note that the procedure was tested with higher VIC values. However, the number of samples was observed to decrease drastically, leading us to choose the value of $1 \mathrm{~mm}$. Petersen et al. (2005) showed that this value corresponds to the beginning of a relationship between vertical ice content and lightning flash density. 

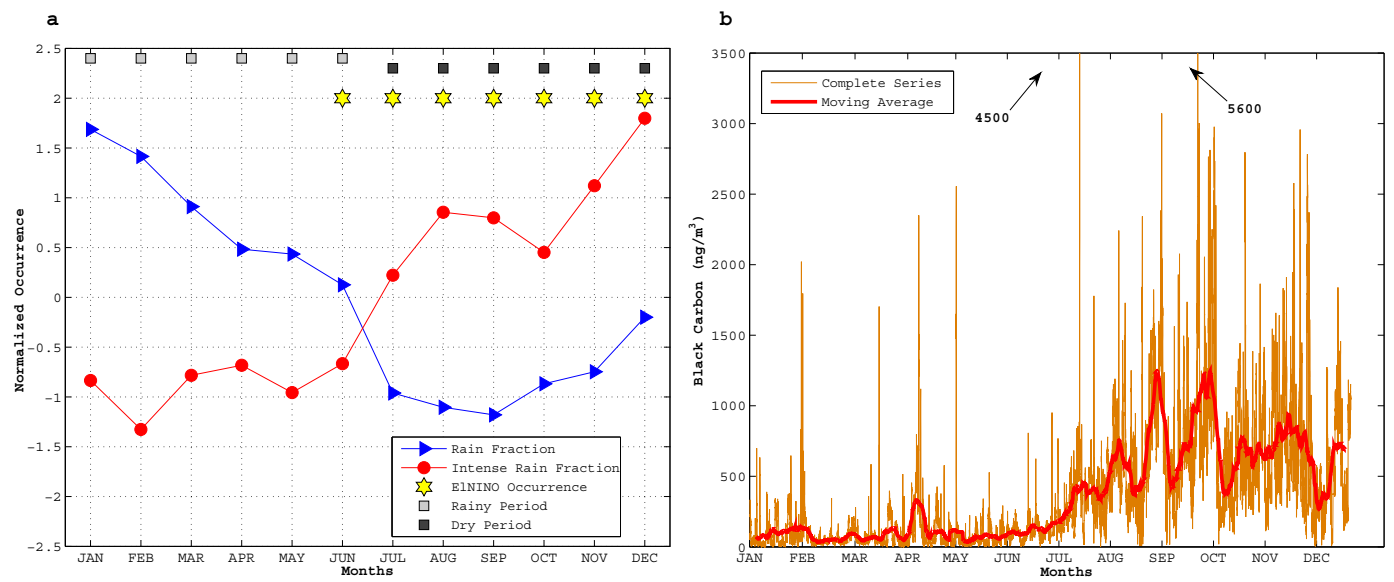

Figure 1. (a) Annual cycle of rain fraction (RF) and intense rain fraction (IRF) values normalized by their annual means and standard deviations for the S-band radar located in Manaus in 2009. The symbols at the top of the panel represent the rainy period (light gray squares), the dry period (dark gray squares), and El Niño occurrence (yellow stars). (b) Annual cycle of black carbon (BC) for Manaus in 2009. The orange line represents the complete series in $30 \mathrm{~min}$ intervals for each measurement, and the thick red line represents a weekly moving average.
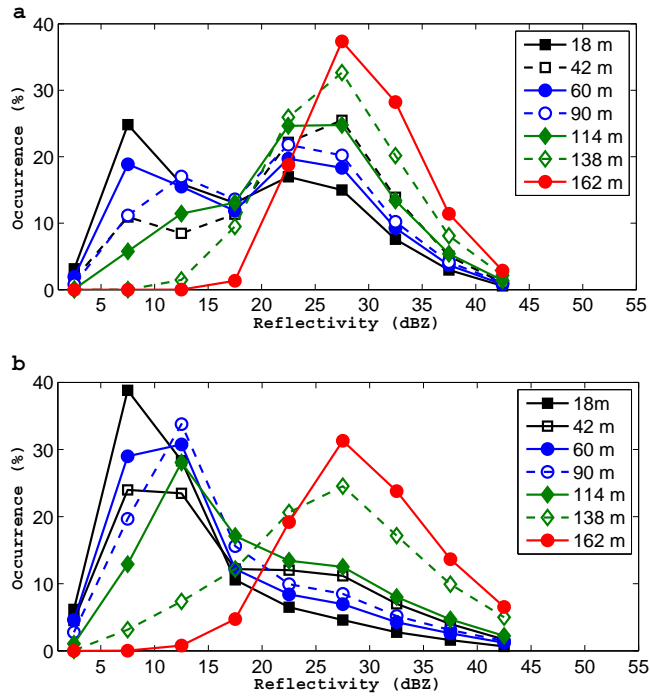

Figure 2. Frequency histograms of radar reflectivity for different topography elevations (intervals of $24 \mathrm{~m}$ ) for the S-band radar located in Manaus in 2009. (a) Rainy season; (b) dry season.

The algorithm known as Forecast and Tracking the Evolution of Cloud Clusters (FORTRACC), described in detail by Vila et al. (2008), is capable of tracking the evolution of cloud systems. Originally, FORTRACC was applied on infrared images from geostationary meteorological satellites. The FORTRACC version used in this study is adapted to meteorological radars. FORTRACC was used to describe the size and duration of the rain cells. CAPPI-Ground images were used to track rain cells around the city of Manaus; cells were defined using the $20 \mathrm{dBZ}$ threshold.
As presented previously, the data sets do not share the same temporal sampling frequency. A methodology was applied to collocate them in time. All variables derived from the radar samples (RF, IRF, IF, and size and duration of the rain cells) were collected from the atmospheric soundings within $\pm 2 \mathrm{~h}$ of each other. This consideration was made because only two atmospheric soundings were available during each day. As a result, the atmospheric stability, inferred by CAPE, was considered constant within $\pm 2 \mathrm{~h}$ of the sounding launch time. The BC concentrations with the closest measurement times to the radar data were used. This temporal matching of the variables allowed us to understand the aerosol effect on precipitation in the Amazon basin.

\section{The seasonal evolution of black carbon concentration and convective processes}

The Manaus precipitation characteristics were obtained from the RF and IRF data. The RF and IRF values were normalized by their annual means and standard deviations to compare both annual cycles. The result (Fig. 1a) was useful in determining two distinct periods with which to perform the analysis. Months during which the normalized RF value was greater or smaller than zero were considered to comprise the rainy or dry seasons, respectively. The period between January and June was identified as the rainy season, and the period between July and December as the dry season. From previous studies, it is known that a strong increase in the level of precipitation occurs in the months of November and December. However, in our analysis, only a slight increase in the normalized RF was observed (Fig. 1a). This behavior could be attributed to an observed El Niño configuration, which potentially decreases the precipitation in the Amazon. Another 

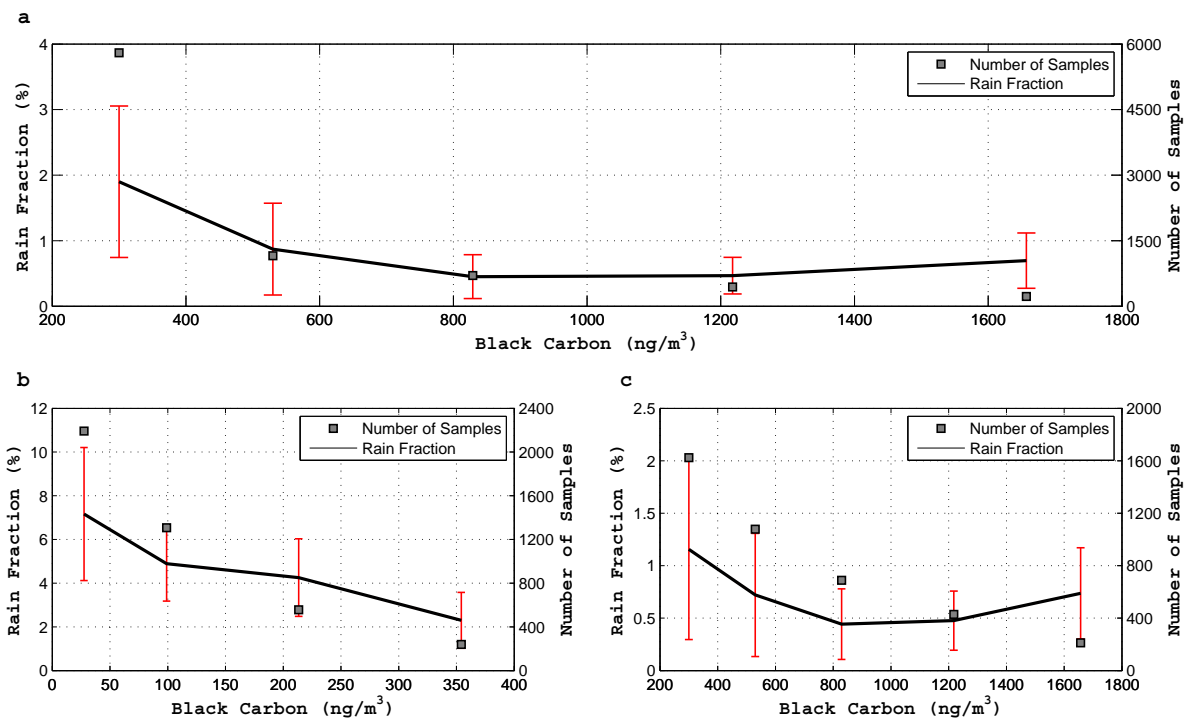

Figure 3. Mean, standard deviation, and number of samples of rain fraction (RF) for different black carbon (BC) concentrations. (a) Entire year; (b) rainy season; (c) dry season. For these curves, no atmospheric stability consideration was performed.

important aspect is that the normalized IRF value is higher within the dry period (Fig. 1a). The frequency of intense precipitation increases mainly toward the end of the dry season. This increase is related to a reduction in the inversion layer and an increase in CAPE and moisture due to the monsoon circulation (Machado et al., 2004). This result indicates that in the dry period, when large-scale precipitation decreases in the study area, most of the precipitation is related to intense convection, which mainly occurs over elevated areas.

Even with small variations in terrain elevations, with the highest point at approximately $160 \mathrm{~m}$, a notable precipitation feature within the study domain is found to be related to the topography (Fig. 2). For the rainy period (Fig. 2a), all of the elevations had a reflectivity peak greater than $20 \mathrm{dBZ}$ (approximately $1 \mathrm{~mm} \mathrm{~h}^{-1}$ ). In other words, precipitation occurs in a nearly spatially homogeneous manner during the rainy season despite a high peak of reflectivity observed over elevated regions. During the dry season (Fig. 2b), reflectivity peaks greater than $20 \mathrm{dBZ}$ were only observed over elevated areas. This suggests that in the absence of a large scale circulation that could support the precipitation, the upslope triggering plays an important role in the formation of rain cells. Importantly, the two last categories of elevations presented in Fig. 2 are more than $60 \mathrm{~km}$ from the radar. At this distance, the lower radar elevation band is approximately $1 \mathrm{~km}$ high, which eliminates the possibility of effects from ground clutter. An important test was performed to ensure that the influence of topography on the rain systems would not lead to misinterpretations of the aerosol-precipitation relationship. Details of this test are presented in Sect. 4.

In addition to precipitation characteristics, the annual cycle of BC concentration (Fig. 1b) was considered for separating the analyses into rainy/dry periods. During the rainy sea- son, the $\mathrm{BC}$ concentration was below $700 \mathrm{ng} \mathrm{m}^{-3}$ for almost the entire period. This low concentration could be explained by wet deposition or the absence of large sources of biomass burning (Martin et al., 2010). On the other hand, for the other six months, the $\mathrm{BC}$ concentration increased, mainly due to a high number of deforestation fires in the region (Artaxo et al., 2006) and a decrease in the observed precipitation. This characteristic favors the outbreak of fires in the forest, allowing them to spread over the region.

\section{The effect of instability on the rainfall-aerosol relationship}

\subsection{Observational evidence}

The first analysis focused on the overall relationship between BC concentrations and the rain characteristics (Fig. 3). At this stage, no consideration was made regarding the filtering of a possible BBA effect on precipitation from another atmospheric feature. For the rainy period (Fig. 3b), a decrease in RF was observed as BC concentration increased. In contrast, during the dry period (Fig. 3c), a decrease in RF was observed, up to approximately $1000 \mathrm{ng} \mathrm{m}^{-3}$ of BC. Beyond this value, the RF slightly increased. Although it was not statistically significant, this characteristic led us to attempt a filtering out of the possible aerosol influence on precipitation from an atmospheric feature that could modulate this effect. At this stage, CAPE was chosen as the atmospheric component. Therefore, the precipitation/BC comparisons were performed for less unstable (CAPE $<1400 \mathrm{~J} \mathrm{~kg}^{-1}$, i.e., less convective activity) and more unstable (CAPE $>2600 \mathrm{~J} \mathrm{~kg}^{-1}$, i.e., more convective activity) atmospheres. These values are 
a

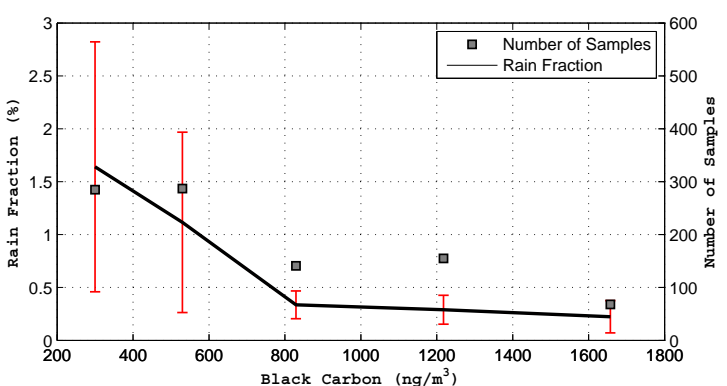

b

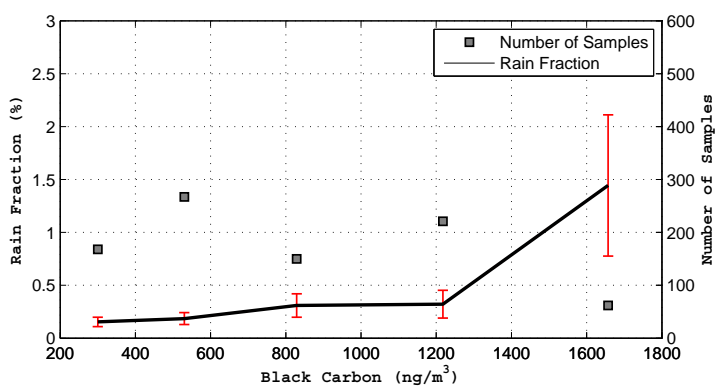

c

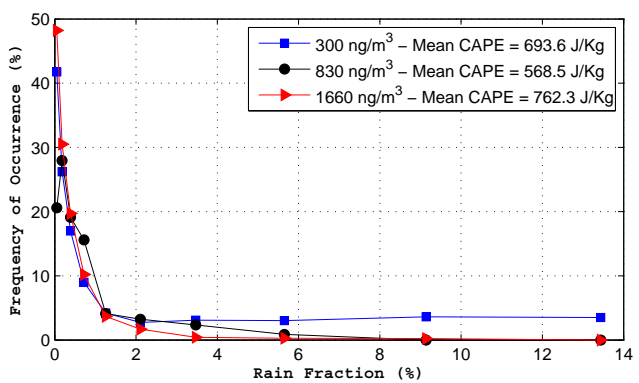

$d$

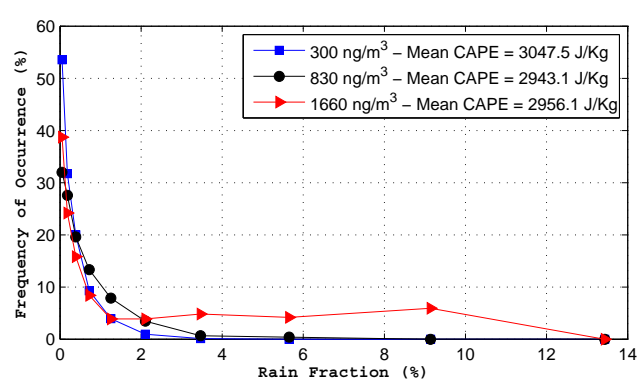

Figure 4. Mean, standard deviation, and number of samples of rain fraction (RF) for different black carbon (BC) concentrations for less unstable (a) and more unstable (b) atmospheres in the dry period. RF frequency histograms for the first, third, and fifth BC concentrations in (a) and (b), are shown for less unstable (c) and more unstable (d) atmospheres. The first and third curves in (c) and (d) are significantly different as determined by a $t$ test at the $95 \%$ confidence level.

similar to those presented by Wallace and Hobbs (2006), and found to be appropriate for dividing the convective activity according to the CAPE value.

A test was applied prior to the study to determine whether the scavenging process was significant in the study area. The main objective of this study was to identify the influence of BBA on precipitation. However, precipitation can also modify BBA concentrations in the atmosphere, due to the wet scavenging process. As previously mentioned, the $\mathrm{BC}$ measurements were made in situ, approximately $50 \mathrm{~km}$ from the city of Manaus, in the state of Amazonas. Thus, the concept of this test was based on eliminating all samples from our statistics for which precipitation was observed over the EUCAARI site. This filtering excluded the samples in which precipitation could have cleaned the atmosphere, throughout the scavenging process. After this, comparisons between the RF and BC concentrations were performed. No significant differences were observed when comparing the results utilizing this criterion with those in which no consideration was given to a potential aerosol wet scavenging effect. This characteristic indicates that the local scavenging effect seems to be of a second order on the BC-rain interaction. However, this test does not take into account the reduction of BC sources outside the measurement site due to rainfall. Therefore, it is not possible to separate the scavenging effect from other physical effects associating reduction of rainfall with the increase in $\mathrm{BC}$ concentration, even if the scaveng- ing effect seems to be of a second order, locally. In addition, Gryspeerdt et al. (2015) commented that the time difference between the measurements of rain properties and aerosol could lead to misinterpretations in the aerosol-rainfall relationship, as the timescale of wet scavenging is narrow. In this study, the temporal sampling frequency difference between the EUCAARI and radar measurements is five minutes in the worst case scenario. This sampling time difference, though minor, could have allowed the scavenging effect to remain even with the use of the described test.

As described in Sect. 3, terrain elevation plays an important role in triggering precipitation in the region, mainly during the dry season (Fig. 2b). In the statistical analyses performed herein, no consideration was made for the topography in the analysis of the $\mathrm{BC}$-precipitation relationship. However, to make sure that no considerations were necessary, a relevant test was performed to avoid misinterpretations of the conclusions regarding the comparisons between the rainfall characteristics and their association with $\mathrm{BC}$ concentrations. This test was conducted to verify whether the BC-precipitation relationship was different for each topography category presented in Fig. 2. For each category, we compared the RF values for different BC concentrations in less and more unstable atmospheres. The results for each terrain elevation category were statistically similar to the statistical analyses described below. Therefore, though important for triggering precipitation, the elevation did not influence 
a

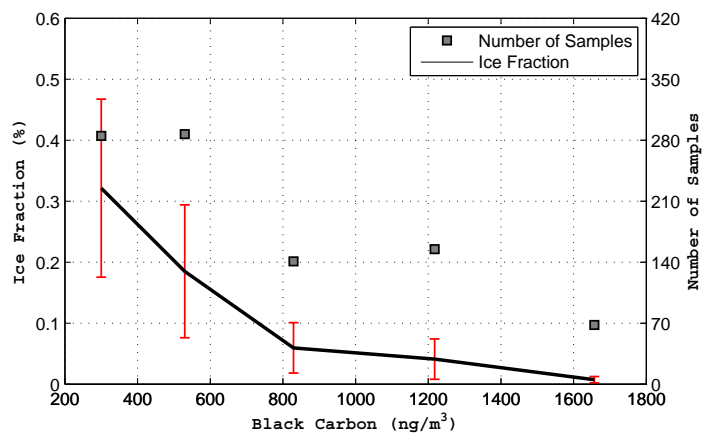

$\mathrm{b}$

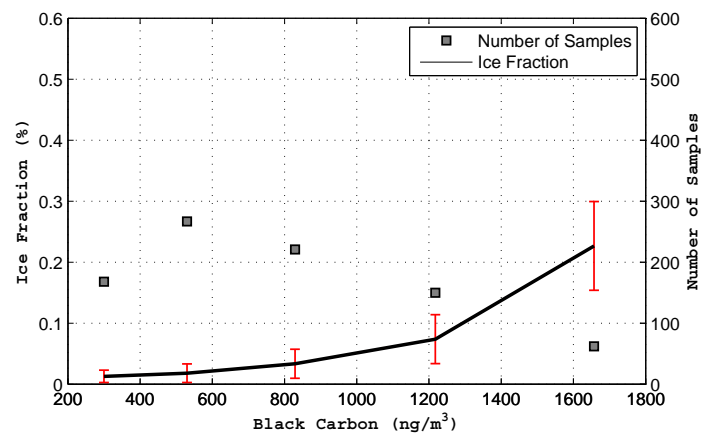

c

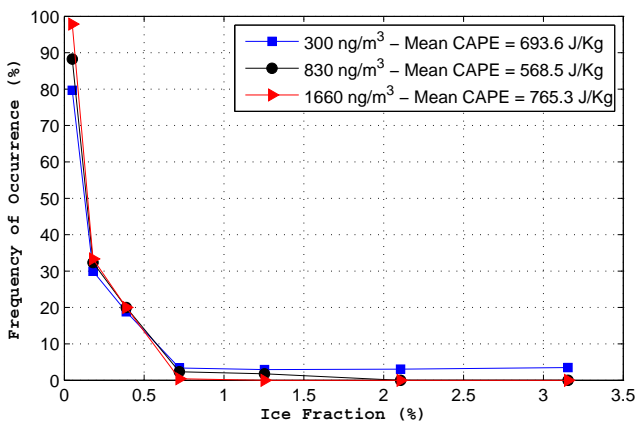

d

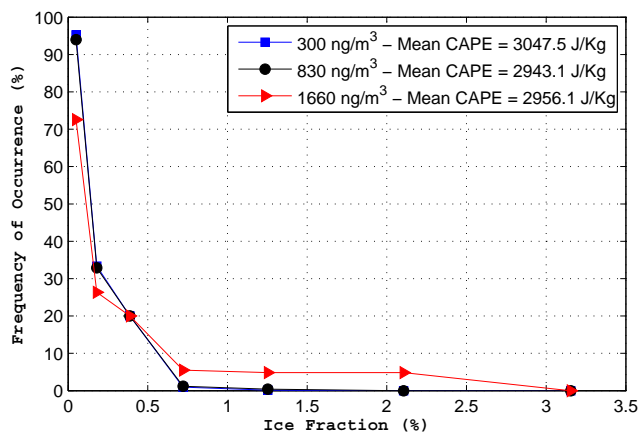

Figure 5. Mean, standard deviation, and number of samples of ice fraction (IF) for different black carbon (BC) concentrations for stable (a) and unstable (b) atmospheres in the dry period. IF frequency histograms for the first, third, and fifth BC concentrations in (a) and (b) are shown for less unstable (c) and more unstable (d) atmospheres. The first and third curves in (c) and (d) are significantly different at as determined by a $t$ test at the $95 \%$ confidence level.

the results related to $\mathrm{BC}-$ precipitation comparisons, which allowed us to use all grid points in our study, independently of their elevation.

The two important tests previously described help to reinforce the evidence of the influence of BBA on the rainfall characteristics presented hereafter. During the wet period, no differences were observed for the less and more unstable cases. The behavior was identical to that obtained when no atmospheric considerations were performed (Fig. 3b). A similar pattern was observed for the less unstable cases during the dry season (Fig. 4a). In support of this result, the RF distributions (Fig. 4c) presented a more elongated tail for the small BC concentrations. This decrease could be associated with the suppression of warm or stratiform precipitation because it is unlikely that a strong convection could form in stable cases. The exact opposite behavior was found for the more unstable atmospheres within the dry period (Fig. 4b). The RF increased in cases where higher concentrations of BC were observed. The precipitation appeared to spread over the region when the atmosphere was favorable to the development of convection associated with BBA. The distribution of RF for three categories of BC (Fig. 4d) shows that the greater the particulate material concentration, the more elongated the tail of the RF distributions. As commented in Sect. 2, RF is an indication of the distribution of rain in the study domain. Therefore, an increase in values for this variable for polluted atmospheres does not necessarily mean that more intense convection is occurring. However, this behavior was observed when the atmosphere presented conditions for intense convection. Consequently, this result could be an indication that convection is invigorated by higher BBA concentrations (Lin et al., 2006; Graf, 2004; Rosenfeld et al., 2008; Altaratz et al., 2010; Koren et al., 2012) when the atmosphere is highly unstable (i.e., presenting high CAPE values).

An analysis evaluating the presence of ice in the precipitating cells within polluted atmospheres has the potential to give support to the previously described evidence. Therefore, to understand whether the amount of cloud ice is influenced by the presence of high BBA concentrations, the IF index was calculated based on Eq. (3). This procedure was important to account for the fact that ice formation could be influenced by BC (DeMott et al., 1999; Cozic et al., 2008; Kireeva et al., 2009). In addition to the convective case hypothesis, we verified whether the precipitation suppression observed for the less unstable case could link to the presence of stratiform clouds. The mean IF values decreases substantially in proportion to the increase in $\mathrm{BC}$ concentration for less unstable atmospheres (Fig. 5a). This result could be an indication 


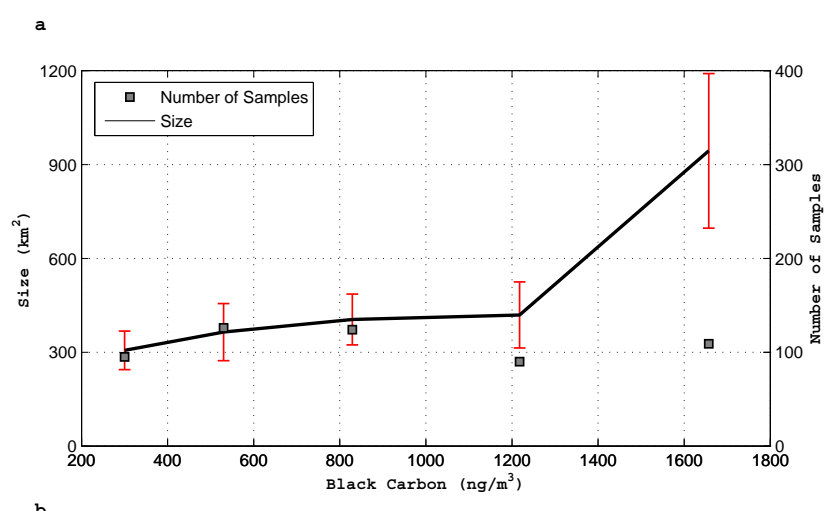

b

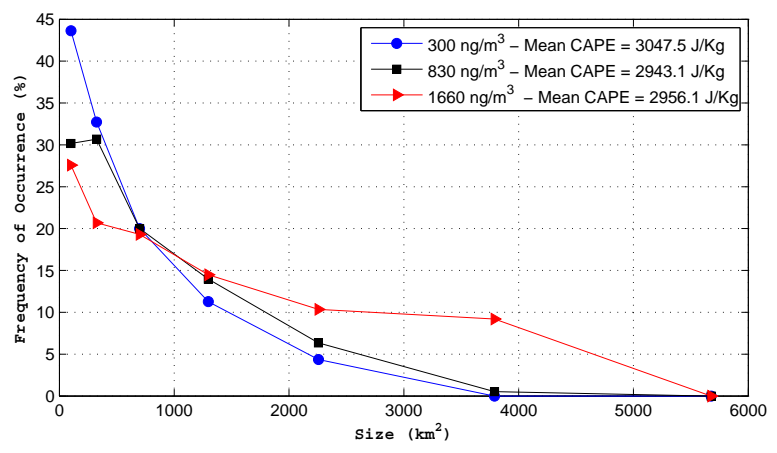

Figure 6. (a) Mean, standard deviation, and number of samples of rain cell size $\left(>100 \mathrm{~km}^{2}\right)$ for different black carbon (BC) concentrations in a more unstable atmosphere during the dry period; (b) size frequency histograms for the first, third, and fifth BC concentrations in (a). The first and third curves in (b) are significantly different, as determined by a $t$ test at the $95 \%$ confidence level.

that stratiform clouds are negatively influenced by BBA. In more unstable cases, the result indicates that the convection invigoration hypothesis (Rosenfeld et al., 2008) based on the presence of aerosols is likely to be true (Fig. 5b), in agreement with the RF-BC relationship previously indicated.

The RF-IF/BC analyses were useful for understanding the increase/decrease in precipitation or ice fraction over the entire radar coverage area. However, they do not give information on the space and time scale organization of the rainfall. FORTRACC was employed to evaluate whether BBA changes the lifetime duration of the rain cells. First, rain cells resulting from splitting or merging were eliminated from the data for the duration analysis. In fact, splitting or merging modify the physical characteristics of the precipitating systems, influence their duration, and compromise the evaluation of the BBA effect on them. In addition, rain cells that do not have their entire lifecycle inside the radar domain were not considered, as it was not possible to determine the lifetime of a rain cell that did not initiate and dissipate inside the radar domain. These filters drastically decrease the sample of rain cells analyzed. The results showed no significant change in the lifetime duration as a function of BBA. Unfortunately, the lifecycle rain cell population was not statisti- cally significant after all these considerations. However, the study of the rain cell size distributions is not subject to any of these limitations, and all rain cells, regardless of whether they had their entire lifecycle inside the domain region, can be taken into account. For the rainy season, no significant effect was observed on the rain cell size relationship with the $\mathrm{BC}$ concentration. The same pattern was observed for the dry season, except for rain cells larger than $100 \mathrm{~km}^{2}$ in more unstable atmospheres. For systems smaller than $100 \mathrm{~km}^{2}$, even in high instability cases, the increase in $\mathrm{BC}$ concentration does not exhibit any significant relationship with rain cell size. However, for larger rain cells (Fig. 6a), in unstable atmospheres during the dry season, the rain cell size increases as a function of the $\mathrm{BC}$ concentration. Although a large variability can be noted in Fig. 6, the tail of the rain cell size distribution shows a larger size for higher BC concentrations (Fig. 6b). Moreover, the curves are significantly different, as determined by using a $t$ test with a $95 \%$ confidence level. The presence of particulate material appears to reinforce the convection that is well established by the increased level of atmospheric instability. The mean system area increases from 300 to over $900 \mathrm{~km}^{2}$ as BC concentration varies from 300 to $1660 \mathrm{ng} \mathrm{m}^{-3}$.

\subsection{Discussion of the possible physical mechanisms}

In our analyses, we observed that polluted atmospheres are generally associated with decreased precipitation. This behavior was also evident for the dry season in less unstable atmospheres. However, during the dry season in more unstable atmospheres, RF and IF increase as BC concentration increases. In this section we discuss some physical mechanisms potentially related to these observations. Although it was not possible to evaluate the cloud droplet size distribution with the data set used in this study, a mechanism responsible for the observed behavior can still be suggested. The decreases in RF and IF with increasing BC could be related to enhanced formation of cloud droplets with reduced size (Rosenfeld, 1999; Ramanathan et al., 2001), compromising the coalescence process (Kaufman et al., 2005). In the absence of strong buoyancy, the small droplets do not ascend to high atmospheric levels, and evaporate easily or do not develop to a rainfall drop size, in a mechanism similar to warm precipitation suppression. The wet scavenging process, an important component responsible for the removal of aerosol in the atmosphere, could also contribute to the results observed, mainly for lower BC concentrations, at which the RF and IF reach their higher values. Moreover, it is not possible to define which effect (semi-direct or indirect) dominates or what the feedback between them is. As the RF and IF decrease for elevated $\mathrm{BC}$ concentrations, the dominant effect could be explained by the wet deposition theory and/or the rain suppression theory. In addition, the radiative effect acts to increase the population of stable atmosphere cases and results in less rainfall for the situation of high aerosol loading. 
Table 1. Observed features and proposed mechanisms for stable and unstable atmospheres during dry and wet seasons.

\begin{tabular}{|c|c|c|}
\hline $\begin{array}{l}\text { Atmosphere state } \\
\text { Wet season }\end{array}$ & Observed features & $\begin{array}{l}\text { Possible mechanisms explaining } \\
\text { this behavior: }\end{array}$ \\
\hline $\begin{array}{l}\text { Less unstable } \\
\left(\mathrm{CAPE}<1400 \mathrm{~J} \mathrm{~kg}^{-1}\right)\end{array}$ & $\begin{array}{l}\text { - RF and IF decreases as BC increases; } \\
\text { - low BC concentration; } \\
\text { - no influence on rain cell size; }\end{array}$ & $\begin{array}{l}\text { - the wet scavenging process, greater for- } \\
\text { mation of cloud droplets with reduced size } \\
\text { suppressing precipitation; } \\
\text { - atmosphere stabilization; }\end{array}$ \\
\hline $\begin{array}{l}\text { More unstable } \\
\left(\text { CAPE }>2600 \mathrm{~J} \mathrm{~kg}^{-1}\right)\end{array}$ & $\begin{array}{l}\text { - RF and IF decreases as BC increases; } \\
\text { - low BC concentration; } \\
\text { - no influence on rain cell size; }\end{array}$ & $\begin{array}{l}\text { - the wet scavenging process, greater for- } \\
\text { mation of cloud droplets with reduced size } \\
\text { suppressing precipitation; }\end{array}$ \\
\hline $\begin{array}{l}\text { Atmosphere state } \\
\text { Dry season }\end{array}$ & observed features & $\begin{array}{l}\text { possible mechanisms explaining } \\
\text { this behavior: }\end{array}$ \\
\hline $\begin{array}{l}\text { Less unstable } \\
\left(\text { CAPE }<1400 \mathrm{~J} \mathrm{~kg}^{-1}\right)\end{array}$ & $\begin{array}{l}\text { - RF and IF decreases as BC increases; } \\
\text { - high polluted atmosphere } \\
\left(>1000 \mathrm{ng} \mathrm{m}^{-3}\right) \\
\text { - no influence on rain cell size; }\end{array}$ & $\begin{array}{l}\text { - the wet scavenging process, greater for- } \\
\text { mation of cloud droplets with reduced size } \\
\text { suppressing precipitation; } \\
\text { - atmosphere stabilization; } \\
\text { - less buoyancy; } \\
\text { - weaker updrafts; } \\
\text { - weaker homogenous ice formation; }\end{array}$ \\
\hline $\begin{array}{l}\text { More unstable } \\
\left(\mathrm{CAPE}>2600 \mathrm{~J} \mathrm{~kg}^{-1}\right)\end{array}$ & $\begin{array}{l}\text { - RF and IF increases as BC increases; } \\
- \text { high polluted atmosphere } \\
\left(>1000 \mathrm{ng} \mathrm{m}^{-3}\right) \\
\text { - increase in rain cell size as BC increases, } \\
\text { only for large rain cell areas }\left(>100 \mathrm{~km}^{2}\right)\end{array}$ & $\begin{array}{l}\text { - high buoyancy; } \\
\text { - stronger updrafts; } \\
\text { - high homogenous ice formation; } \\
\text { - more latent heating; } \\
\text { - convection invigorated; } \\
\text { - smaller entrainment for large rain cells }\end{array}$ \\
\hline
\end{tabular}

During the dry season, in a more unstable condition, our results indicate an invigoration of the precipitation with increasing BC concentration. Considering that high CAPE values are associated with stronger updrafts, the aerosol effect on the rainfall and on the severity of the convective processes could depend on the intensity of the vertical motions. In addition, it is important to note that during the dry season, only elevated regions trigger convection, which could support the intensification of the updrafts in more unstable atmospheres. The radiative effect, which also acts to stabilize the atmosphere, is probably of a second order. Even with high levels of BBA, the atmosphere is highly unstable, and thermodynamics on this time scale seem to dominate over the radiative process. Additionally, an increase in the droplet evaporation process, which could be generated by the radiative effect, does not seem to be the predominant mechanism. Probably due to the high instability (high updraft), the large number of small droplets inside clouds (formed by the microphysical effect) ascend very fast, thereby reducing the extent of evaporation. Rosenfeld et al. (2008) commented that an unstable atmosphere could carry the small droplets to higher atmospheric levels, invigorating convection and increasing the amount of ice. Moreover, BC particles could be carried within the updrafts and act as ice nuclei. During the dry season, most of the precipitation is associated with elevated regions, and in the more unstable cases, it appears that BBA helps to increase ice nuclei formation and precipitation. Although impossible to quantify, the wet scavenging process also seems to be of second order. It would act in the opposite direction through the fact that RF and IF are higher for polluted atmospheres (Figs. $4 \mathrm{~b}$ and 5b). Notably, however, it is possible that for small IF and RF values, the effect of the wet scavenging process is still present in the statistical analyses. In these cases, the applied wet scavenging test may not have been able to identify this process. The last result presented in the previous section was related to the consequence of the BBA loading on the size of the precipitating systems. Agreeing with the RF/IF analyses, polluted atmospheres seem to influence the development of larger precipitating systems for the more unstable cases in the dry season. However, as commented before, this effect was only observed for systems larger than $100 \mathrm{~km}^{2}$. This result is probably due to the entrainment effect, which depends inversely on cloud radii in the updrafts (Simpson and Wiggert, 1969). Larger rain cells have smaller entrainment, favoring higher levels of neutral buoyancy. Storelvmo (2012) also commented that the entrainment rate plays an important role in the aerosol effect on deep convective clouds. In addition, it is important to note that Koren et al. (2012) observed that rain cells occurring under polluted conditions had their coverage area increased by approximately $20 \%$, which also lends support to the results presented in this research. The main results presented in this 
study and the mechanisms proposed are summarized in Table 1 .

\section{Conclusions and discussions}

This study evaluates the relationship between precipitation and $\mathrm{BC}$ concentration using data from 1 year of ground observations. The results presented are innovative and independent; most prior studies have relied on satellite remote sensing. The methodology using observational data presented herein may contribute to the knowledge of the BBA effect on precipitating systems in the Amazon basin. One of the greatest difficulties regarding this issue has been filtering the aerosol effect from other important atmospheric features. Large-scale circulation or thermodynamic effects represent a major component underlying the strengthening of convection. An analysis of the contribution of each effect could not be performed observationally, but through theoretical simulations that are not completely parameterized. In this study, CAPE values were used as the atmospheric filtering component, which allowed us to divide analyses according to the degree of atmospheric stability. Important features, such as wet scavenging, synoptic scale influence, and droplet size distribution characteristics, need further study and improvement to extend this result. As BBA is predominant in the Amazon basin, BC was used as an aerosol tracer. Nevertheless, other types of aerosol are also present in the region and should receive more attention in new field campaigns. The El Niño configuration, as was observed during the dry season, is associated with reduced levels of precipitation and a decrease in the occurrence of rain cells. Even if this situation had decreased the rain cell population used to study the lifetime duration, a significant number of samples were analyzed for the evaluation of the aerosol-rainfall interaction, and this did not compromise the main results of this study that are associated with the convective scale.

Despite the limitations of the database and the large set of independent variables, the results presented in this study were statistically significant and physically relevant. BBA releases into the atmosphere generally appear to contribute to a decrease in precipitation. It has been difficult to define the main factor responsible for this behavior because there are several effects, such as wet scavenging or atmosphere inhibitions, which cannot be excluded from the results and could also contribute to precipitation reduction. Nevertheless, we postulate a probable physical mechanism that could explain the observed results as follows. The decrease in RF and IF could be associated to the warm rain suppression mechanism linked to the radiative effect, or to an association of the radiative and microphysical effects together. The most important result obtained in this research was the difference in the rain features analyzed during the dry season for less and more unstable atmospheres. The convective invigoration of polluted atmospheres was only observed in more unstable atmospheres. This appears to be a considerably significant result, based on the fact that the wet scavenging process acts in the opposite direction, reducing precipitation. The wet scavenging appears to be of a second order in the precipitation-aerosol relationship for elevated concentrations of BC. However, it was only possible to obtain a qualitative result because it was not possible to isolate this process for the precipitation inhibition cases and quantify the exact effect on the rain and ice fractions. Based on the results, we could again postulate a probable physical mechanism which could explain the observed behavior. We observed that during the dry season, most convection occurs in elevated areas. Thus, in more unstable cases, stronger updrafts inside the rain cells initiated over those elevated regions probably carry a greater quantity of droplets formed in a polluted environment to high tropospheric levels, producing in the clouds changes related to their microphysical properties, dynamics and thermodynamics. We were unable to measure the quantity of droplets formed due to the microphysical effect, and the vertical velocity within the precipitating systems was not available in the database used. However, the vertical velocity can be directly linked to CAPE values because the greater the atmospheric instability is, the stronger the updrafts are. This study does not define any specific BC concentration that could activate the cloud process, possibly increasing convective strengthening. Nevertheless, it has been shown that this process only occurs significantly when the $\mathrm{BC}$ concentration is higher than $1200 \mathrm{ng} \mathrm{m}^{-3}$.

The indication of the influence of BBA on the size of the rain cells followed the same behavior observed for RF and IF. We again suggest that the effect is modulated by the atmospheric degree of instability. An important size threshold was found, and the relationship between BC concentration and rain cells area seems to depend on it. The influence of BBA on convective strengthening was observed for large rain cells. This effect is probably related to the reduced entrainment of dry air parcels into the convection, favoring a higher level of neutral buoyancy. The area increase was only observed for systems larger than $100 \mathrm{~km}^{2}$ for the more unstable cases in the dry period. Although the analysis of the influence of BBA on the longevity of the rain cells has been inconclusive, some evidence of this relationship should be mentioned. It is well known that the size of rain cells is positively correlated to their longevity. Thus, the results presented in this study could be an indication that high concentrations of BC could lead to longer lifetime rain cells, depending on the atmospheric degree of instability.

Acknowledgements. This study was funded by the following grants: CNPq-141952/2010-5 and FAPESP CHUVA project 2009/15235-8. We thank Paulo Artaxo for the discussions and for providing the EUCAARI database, and the Amazon Protection National System (SIPAM) for the S-band radar data set.

Edited by: P. Stier 


\section{References}

Ahmed, T., Dutkiewicz, V. A., Khan, A. J., and Husain, L.: Long term trends in Black Carbon Concentrations in the Northeastern United States, Atmos. Res., 137, 49-57, 2014.

Altaratz, O., Koren, I., Yair, Y., and Price, C.: Lightning response to smoke from Amazonian fires, Geophys. Res. Lett., 37, L07801, doi:10.1029/2010GL042679, 2010.

Altaratz, O., Koren, I., Remer, L. A., and Hirsch, E.: Review: Cloud invigoration by aerosols-Coupling between microphysics and dynamics, Atmos. Res., 140-141, 38-60, 2014.

Andreae, M. O., Rosenfeld, D., Artaxo, P., Costa, A. A., Frank, G. P., Longo, K. M., and Silva-Dias, M. A. F.: Smoking rain cloud over the Amazon, Science, 303, 1337-1342, 2004.

Artaxo, P., Martins, J. V., Yamasoe, M. A., Procópio, A. S., Pauliquevis, T. M., Andreae, M. O., Gunyon, P., Gatti, L. V., and Leal, A. M. C.: Physical and chemical properties of aerosols in the wet and dry seasons in Rondônia Amazônia, J. Geophys. Res., 107, 1-14, doi:10.1029/2001JD000666, 2002.

Artaxo, P., Oliveira, P. H., Lara, L. L., Pauliquevis, T. M., Rizzo, L. R., Junior, C. P., and Paixão, M. A.: Efeitos climáticos de partículas de aerossóis biogênicos emitidos em queimadas na Amazônia, Revista Brasileira de Meteorologia, 21, 168-189, 2006.

Bevan, S. L., North, P. R. J., Grey, W. M. F., Los, S. O., and Plummer, S. E.: Impact of atmospheric aerosol from biomass burning on Amazon dry-season drought, J. Geophys. Res., 114, D09204, doi:10.1029/2008JD011112, 2009.

Borys, R. D., Lowenthal, D. H., and Mitchell, D. L.: The relationships among cloud microphysics, chemistry and precipitation rate in cold mountain clouds, Atmos. Environ., 34, 2593-2602, 2000.

Borys, R. D., Lowenthal, D. H., Cohn, S. A., and Brown, W. O. J.: Mountaintop and radar measurements of anthropogenic aerosol effects on snow growth and snowfall rate, Geophys. Res. Lett., 30, 1538, doi:10.1029/2002GL016855, 2003.

Brioude, J., Cooper, O. R., Feingold, G., Trainer, M., Freitas, S. R., Kowal, D., Ayers, J. K., Prins, E., Minnis, P., McKeen, S. A., Frost, G. J., and Hsie, E.-Y.: Effect of biomass burning on marine stratocumulus clouds off the California coast, Atmos. Chem. Phys., 9, 8841-8856, doi:10.5194/acp-9-8841-2009, 2009.

Camponogara, G., Silva Dias, M. A. F., and Carrió, G. G.: Relationship between Amazon biomass burning aerosols and rainfall over the La Plata Basin, Atmos. Chem. Phys., 14, 4397-4407, doi:10.5194/acp-14-4397-2014, 2014.

Cattani, E., Costa, M. J., Torricella, F., Levizzani, V., and Silva, A. M.: Influence of aerosol particles from biomass burning on cloud microphysical properties and radiative forcing, Atmos. Res., 82, 310-327, 2006.

Cozic, J., Mertes, S., Verheggen, B., Cziczo, D. J., Gallavardin, S. J., Walter, S., Baltensperger, U., and Weingartner, E.: Black carbon enrichment in atmospheric ice particle residuals observed in lower tropospheric mixed phase clouds, J. Geophys. Res., 113, $1-11,2008$

D’Andrea, S. D., Häkkinen, S. A. K., Westervelt, D. M., Kuang, C., Levin, E. J. T., Kanawade, V. P., Leaitch, W. R., Spracklen, D. V., Riipinen, I., and Pierce, J. R.: Understanding global secondary organic aerosol amount and size-resolved condensational behavior, Atmos. Chem. Phys., 13, 11519-11534, doi:10.5194/acp-1311519-2013, 2013.
Delrieu, G., Boudevillain, B., Nicol, J., Chapon, B., Kirstetter, P. E., Andrieu, H., and Faure, D.: Bollène 2002 experiment: radar quantitative precipitation estimation in the Cévennes-Vivarais region, France, J. Appl. Meteorol. Clim., 48, 1428-1447, 2009.

DeMott, P. J., Chen, Y., Kreidenweis, S. M., Rogers, D. C., and Sherman, D. E.: Ice formation by black carbon particles, Geophys. Res. Lett., 26, 2429-2432, 1999.

Formenti, P., Andreae, M. O., Lange, L., Roberts, G., Cafmeywe, J., Rajta, I., Maenhaut, W., Holben, B. N., Artaxo, P., and Lelieveld, J.: Saharan dust in Brazil and Suriname during the LargeScale Biosphere-Atmosphere Experiment in Amazonia (LBA)Cooperative LBA Regional Experiment (CLAIRE) in March 1998, J. Geophys. Res., 106, 919-934, 2001.

Graf, H. F.: The complex interaction of aerosols and clouds, Science, 303, 1309-1311, 2004.

Graham, B., Guyon, P., Taylor, P. E., Artaxo, P., Maenhaut, W., Glovsky, M. M., Flagan, R. C., and Andreae, M. O.: Organic compounds present in the natural Amazonian aerosol: characterization by gas chromatography-mass spectrometry, J. Geophys. Res., 108, 1-13, doi:10.1029/2003JD003990, 2003.

Gryspeerdt, E., Stier, P., White, B. A., and Kipling, Z.: Wet scavenging limits the detection of aerosol-cloud-precipitation interactions, Atmos. Chem. Phys. Discuss., 15, 6851-6886, doi:10.5194/acpd-15-6851-2015, 2015.

Hansen, J., Sato, M., and Ruedy, R.: Radiative forcing and climate response, J. Geophys. Res., 102, 6831-6864, 1997.

Hudson, J. G. and Mishra, S.: Relationships between CCN and cloud microphysics variations in clean maritime air, Geophys. Res. Lett., 34, L16804, doi:10.1029/2007GL030044, 2007.

Hudson, J. G. and Yum, S. S.: Maritime-continental drizzle contrasts in small cumuli, J. Atmos. Sci., 58, 915-926, 2001.

Jacobson, M. Z.: Effects of biomass burning on climate, accounting for heat and moisture fluxes, black and brown carbon, and cloud absorption effects, J. Geophys. Res., 119, 8980-9002, 2014.

Johnson, B. T., Shine, K. P., and Forster, P. M.: The semi-direct aerosol effect: Impact of absorbing aerosols on marine stratocumulus, Q. J. Roy. Meterol. Soc., 130, 1407-1422, 2004.

Jones, G. S., Christidis, N., and Stott, P. A.: Detecting the influence of fossil fuel and bio-fuel black carbon aerosols on near surface temperature changes, Atmos. Chem. Phys., 11, 799-816, doi:10.5194/acp-11-799-2011, 2011.

Kaufman, Y. J., Koren, J. A., Remer, L. A., Rosenfeld, D., and Rudich, Y.: The effect of smoke, dust, and pollution aerosol on shallow cloud development over the Atlantic Ocean, P. Natl. Acad. Sci. USA, 102, 11207-11212, 2005.

Kireeva, E. D., Popovicheva, O. B., Persiantseva, N. M., Khokhlova, T. D., and Shonija, N. K.: Effect of black carbon particles on the efficiency of water droplet freezing, Colloid J., 71, 353-359, 2009.

Kirstetter, P. E., Andrieu, H., Delrieu, G., and Boudevillain, B.: Identification of vertical profiles of reflectivity for correction of volumetric radar data using rainfall classification, J. Appl. Meteorol. Clim., 49, 2167-2180, 2010.

Kirstetter, P. E., Andrieu, H., Boudevillain, B., and Delrieu, G.: A physically-based identification of vertical profiles of reflectivity from volume scan radar data, J. Appl. Meteorol. Clim., 52, 1645$1663,2013$. 
Koch, D. and Del Genio, A. D.: Black carbon semi-direct effects on cloud cover: review and synthesis, Atmos. Chem. Phys., 10, 7685-7696, doi:10.5194/acp-10-7685-2010, 2010.

Koren, I., Kaufman, Y. J., Remer, L. A., and Martins, J. V.: Measurement of the effect of Amazon smoke on inhibition of cloud formation, Science, 303, 1342-1345, 2004

Koren, I., Martins, J. V., Remer, L. A., and Afargan, H.: Smoke invigoration versus inhibition of clouds over the Amazon, Science, 321, 946-949, 2008.

Koren, I., Altaratz, O., Remer, L. A., Feingold, G., and Martin, V.: Aerosol-induced intensification of rain from the tropics to the mid-latitudes, Nat. Geosci., 5, 118-122, 2012.

Lin, J. C., Matsui, T., Pielke, R. A., and Kummerow, C.: Effects of biomass-burning-derived aerosol on precipitation and cloud in the Amazon basin: a satellite-based empirical study, J. Geophys. Res., 111, 1-14, D19204, doi:10.1029/2005JD006884, 2006.

Liu, J. and Li, Z.: Estimation of cloud condensation nuclei concentration from aerosol optical quantities: influential factors and uncertainties, Atmos. Chem. Phys., 14, 471-483, doi:10.5194/acp14-471-2014, 2014.

Machado, L. A. T., Laurent, H., Dessay, N., and Miranda, I.: Seasonal and diurnal variability of convection over the Amazonia: A comparison of different vegetation types and large scale forcing, Theor. Appl. Climatol., 78, 61-77, 2004.

Mahowald, N.: Aerosol indirect effect on biogeochemical cycles and climate, Science, 224, 794-796, 2011.

Marshall, J. S. and Palmer, W.: The distribution of raindrops with size, J. Atmos. Sci., 5, 165-166, 1948.

Martin, S. T., Andreae, M. O., Artaxo, P., Baumgardner, D., Chen, Q., Goldstein, A. H., Guenther, A., Heald, C. L., Mayol-Bracero, O. L., McMurry, P. H., Pauliquevis, T., Poschl, U., Prather, K. A., Roberts, G. C., Saleska, S. R., Silva Dias, M. A., Spracklen, D. V., Swietlicki, E., and Trebs, I.: Sources and proprieties of Amazonian aerosol particles, Rev. Geophys., 48, 1-42, RG000280, doi:10.1029/2008RG000280, 2010.

McFarquhar, G. M. and Heymsfield, A. J.: Parameterizations of INDOEX microphysical measurements and calculations of cloud susceptibility: Applications for climate studies, J. Geophys. Res., 106, 28675-28698, 2001.

Myre, G.: Consistency between satellite-derived and modeled estimates of the direct aerosol effect, Science, 325, 187-190, 2009.

Petersen, W., Christian, H., and Rutledge, S.: TRMM observations of the global relationship between ice water content and lightning, Geophys. Res. Lett., 32, L14819, doi:10.1029/2005GL023236, 2005.

Petters, M. D., Parsons, M. T., Prenni, A. J., DeMott, P. J., Kreidenweis, S. M., Carrico, C. M., Sullivan, A. P., McMeeking, G. R., Levin, E., Wold, C. E., Collett Jr., J. L., and Moosmuller, H.: Ice nuclei emissions from biomass burning, J. Geophys. Res., 114, 1-10, D07209, doi:10.1029/2008JD011532, 2009.

Qian, Y., Gong, D., Fan, J., Leung, L. R., Bennartz, R., Chen, D., and Wang, W.: Heavy pollutions suppresses light rain in China: observations and modelling, J. Geophys. Res., 114, D00K02, doi:10.1029/2008JD011575, 2009.

Ramanathan, V., Crutzen, P. J., Kiehl, T., and Rosenfeld, D.: Aerosols, climate, and the hydrological cycle, Science, 294, 2119-2124, 2001.

Randles, C. A. and Ramaswamy, V.: Direct and semi-direct impacts of absorbing biomass burning aerosol on the climate of southern Africa: a Geophysical Fluid Dynamics Laboratory GCM sensitivity study, Atmos. Chem. Phys., 10, 9819-9831, doi:10.5194/acp-10-9819-2010, 2010.

Roberts, G. C., Andrear, M. O., Zhou, J., and Artaxo, P.: Cloud condensation nuclei in the Amazon Basin: "Marine" conditions over a continent?, Geophys. Res. Lett., 28, 2807-2810, 2001.

Rosenfeld, D.: TRMM observed first direct evidence of smoke from forest fires inhibiting rainfall, Geophys. Res. Lett., 26, 31503108, 1999.

Rosenfeld, D., Lohmann, U., Raga, G. B., O’Dowd, C. D., Kulmala, M., Fuzzi, S., Reissel, A., and Andreae, M. O.: Flood or drought: How do aerosols affect precipitation?, Science, 321, 1309-1313, 2008.

Ryu, S. Y., Kwon, B. G., Kim, Y. J., Kim, H. H., and Chun, K. J.: Characteristics of biomass burning aerosol and its impact on regional air quality in the summer of 2003 at Gwangju, Korea, Atmos. Res., 84, 362-373, 2007.

Simpson, J. and Wiggert, V.: Models of precipitating cumulus towers, Mon. Weather Rev., 97, 471-489, 1969.

Slowik, J. G., Cross, E. S., Han, J., Davidovits, P., Onasch, T. B., Jayne, J. T., Williams, L. R., Canagaratna, R., Worsnop, D. R., Chakrabarty, R. K., Moosmüller, H., Arnott, W. P., Schwarz, J. P., Gao, R., Fahey, D. W., Kok, G. L., and Petzold, A.: An intercomparison of instruments measuring black carbon content of soot particles, Aerosol Sci. Tech., 41, 295-314, 2007.

Storelvmo, T.: Uncertainties in aerosol direct and indirect effects attributed to uncertainties in convective transport parameterizations, Atmos. Res., 118, 357-369, 2012.

Storer, R. L. and Heever, S. C. V. D.: Microphysical processes evident in forcing of tropical deep convective clouds, J. Atmos. Sci., 70, 430-446, 2013.

Tao, W.-K., Chen, J.-P., Li, Z., Wang, C., and Zhang, C.: Impact of aerosol on convective clouds and precipitation, Rev. Geophys., 50, 1-62, 2012.

Tegen, I., Hollrig, P., Chin, M., Fung, I., Jacob, D., and Penner, J.: Contribution of different aerosol species to the global aerosol extinction optical thickness: Estimates from model results, J. Geophys. Res., 102, 895-915, 1997.

Tiwari, S., Srivastava, A. K., Bisht, D. S., Parmita, P., Srivastava, M. K., and Attri, S. D.: Diurnal and seasonal variations of black carbon and $\mathrm{PM}_{2.5}$ over New Delhi, India: Influence of meteorology, Atmos. Res., 125-126, 50-62, 2013.

Vila, D. A., Machado, L. A. T., Laurent, H., and Velasco, I.: Forecast and Tracking the Evolution of Cloud Clusters (ForTraCC) using satellite infrared imagery, methodology and validation, Weather Forecast., 23, 233-245, 2008.

Wake, B.: Aerosol-driven warming, Nature Climate Change, 2, 570-571, 2012.

Wallace, J. M. and Hobbs, P. V.: Atmospheric Science: an Introductory Survey, Academic Press, San Diego, California, USA, 2006.

Wang, C.: Impact of anthropogenic absorbing aerosols on clouds and precipitation: A review of recent progresses, Atmos. Res., 122, 237-249, 2013.

Yum, S. S. and Hudson, J. G.: Maritime/continental microphysical contrasts in stratus, Tellus, 54B, 61-73, 2002. 